\title{
40 YEARS OF EXCELLENCE: AN OVERVIEW OF TECHNOVATION AND A ROADMAPFOR FUTURE RESEARCH
}

\section{Published on Technovation}

\section{Full Text (DOI): $\underline{\text { https://doi.org/10.1016/j.technovation.2021.102303 }}$}

\author{
Marina Dabić \\ Faculty of Economics and Business, University of Zagreb \\ J.F. Kennedy Square 6, 1000 Zagreb, Croatia \\ E-mail: $\underline{\text { mabic@efzg.hr }}$ \\ $\&$ \\ Nottingham Business School, Nottingham Trent University \\ Burton Street NG1 4BU Nottingham, UK \\ E-mail: marina.dabic@ntu.ac.uk \\ Giacomo Marzi \\ Lincoln International Business School, University of Lincoln, \\ Lincoln LN6 7TS, U.K. \\ E-mail: gmarzi@lincoln.ac.uk
}

Bozidar Vlačić

Católica Porto Business School and CEGE, Universidade Católica Portuguesa, Rua de Diogo Botelho 1327, 4169-005 Porto, Portugal

E-mail: bvlacic@porto.ucp.pt

Tugrul U. Daim

Maseeh College of Engineering and Computer Science, Portland State University,

P.O. Box 751, Portland OR 97207-0751, USA

E-mail: tugrul@etm.pdx.edu

Wim Vanhaverbeke

Surrey Business School, University of Surrey, Alexander Fleming Rd, Guildford GU2 7XH, UK

E-mail:w.vanhaverbeke@surrey.ac.uk 


\title{
40 YEARS OF EXCELLENCE: AN OVERVIEW OF TECHNOVATION AND A ROADMAP FOR \\ FUTURE RESEARCH
}

\begin{abstract}
:
The International Journal of Technological Innovation, Entrepreneurship and Technology Management (Technovation) is a flagship journal in the fields of management and technological innovation. This renowned position is largely a result of academic interest, as demonstrated by the large number of citations received from other prestigious journals, as well as downloads from across the globe. This study honors the $40^{\text {th }}$ anniversary of Technovation and provides an overview of the journal's accomplishments since its conception in 1981 using Thomson Reuters Web of Science Core Collection database, complemented by both the Elsevier Scopus and EBSCO Business Premier databases, as well as the journal's webpage. This study highlights the main contributors (i.e. authors, universities, countries accountable for the journal's high ranking), the most cited articles, and the thematic profile of the journal through an extensive bibliometric analysis of Technovation publications. Finally, this study outlines growing research trends and proposes trajectories for future research.
\end{abstract}

Key words: Technovation, Overview, Bibliometric, VOS Viewer, Multiple Correspondence Analysis. 


\section{REFERENCES}

Abraham, B. P., \& Moitra, S. D. (2001). Innovation assessment through patent analysis. Technovation, 21(4), $245-252$.

Alegre, J., \& Chiva, R. (2008). Assessing the impact of organizational learning capability on product innovation performance: An empirical test. Technovation, 28(6), 315-326.

Al-Somali, S. A., Gholami, R., \& Clegg, B. (2009). An investigation into the acceptance of online banking in Saudi Arabia. Technovation, 29(2), 130-141.

Archibugi, D., \& Pianta, M. (1996). Measuring technological change through patents and innovation surveys. Technovation, 16(9), 451-468.

Becheikh, N., Landry, R., \& Amara, N. (2006). Lessons from innovation empirical studies in the manufacturing sector: A systematic review of the literature from 1993-2003. Technovation, 26(5-6), 644-664.

Bellucci, M., Marzi, G., Orlando, B., \& Ciampi, F. (2020). Journal of Intellectual Capital: a review of emerging themes and future trends. Journal of Intellectual Capital. In press

Bergek, A., \& Norrman, C. (2008). Incubator best practice: A framework. Technovation, 28(1-2), 20-28.

Bessant, J., \& Francis, D. (1997). Implementing the new product development process. Technovation, 17(4), 189197.

Bessant, J., Caffyn, S., Gilbert, J., Harding, R., \& Webb, S. (1994). Rediscovering continuous improvement. Technovation, 14(1), 17-29.

Biemans, W. G. (1991). User and third-party involvement in developing medical equipment innovations. Technovation, 11(3), 163-182.

Brady, T., Rush, H., Hobday, M., Davies, A., Probert, D., \& Banerjee, S. (1997). Tools for technology management: An academic perspective. Technovation, 17(8), 417-426.

Brown, W. S., \& Bowen, W. R. (1981) Editorial, Technovation, 1(1), 1-2.

Bruneel, J., Ratinho, T., Clarysse, B., \& Groen, A. (2012). The evolution of Business incubators: Comparing demand and supply of business incubation services across different incubator generations. Technovation, $32(2), 110-121$.

Callon, M., Coenen, R., Cohen, W. M., Freeman, C., Kodama, F., Meyer-Krahmer, F., \& Pisano, G. P. (1999). Retrospective evaluation (1971-1999). Research Policy, 28(9), 911-919.

Caloghirou, Y., Kastelli, I., \& Tsakanikas, A. (2004). Internal capabilities and external knowledge sources: Complements or substitutes for innovative performance? Technovation, 24(1), 29-39.

Carayannis, E. G., Rogers, E. M., Kurihara, K., \& Allbritton, M. M. (1998). High-Technology spin-offs from government R\&D laboratories and research universities. Technovation, 18(1), 1-11.

Cetindamar, D., Phaal, R., \& Probert, D. (2009). Understanding technology management as a dynamic capability: A framework for technology management activities. Technovation, 29(4), 237-246. 
Chiaroni, D., Chiesa, V., \& Frattini, F. (2011). The Open Innovation Journey: How firms dynamically implement the emerging innovation management paradigm. Technovation, 31(1), 34-43.

Chung, S. (2002). Building a national innovation system through regional innovation systems. Technovation, $22(8), 485-491$.

Coldrick, S., Longhurst, P., Ivey, P., \& Hannis, J. (2005). An R\&D options selection model for investment decisions. Technovation, 25(3), 185-193.

Cormican, K., \& O’Sullivan, D. (2004). Auditing best practice for effective product innovation management. Technovation, 24(10), 819-829.

Dabić, M., Vlačić, B., Paul, J., Dana, L-P., Sahasranamam, S., \& Glinka, B. (2020). Immigrant entrepreneurship: a review \& agenda for future research. Journal of Business Research, available online ahead of print at https://doi.org/10.1016/j.jbusres.2020.03.013.

De Man, A. P., \& Duysters, G. (2005). Collaboration and innovation: A review of the effects of mergers, acquisitions and alliances on innovation. Technovation, 25(12), 1377-1387.

Del Brío, J. Á., \& Junquera, B. (2003). A review of the literature on environmental innovation management in SMEs: Implications for public policies. Technovation, 23(12), 939-948.

Ding, Y., Rousseau, R., \& Wolfram, D. (2016). Measuring scholarly impact. Springer International, Berlin, Germany.

Drejer, A. (1997). The discipline of management of technology, based on considerations related to technology. Technovation, 17(5), 253-265.

Dul, J. (2016). Necessary Condition Analysis (NCA): Logic and methodology of "necessary but not sufficient" causality. Organizational Research Methods, 19(1), 10-52.

Ehrnberg, E. (1995). On the definition and measurement of technological discontinuities. Technovation, 15(7), 437-452.

Ernst, H. (1995). Patenting strategies in the German mechanical engineering industry and their relationship to company performance. Technovation, 15(4), 225-240.

Falagas, M. E., Pitsouni, E. I., Malietzis, G. A., \& Pappas, G. (2007). Comparison of PubMed, Scopus, Web of Science, and Google Scholar: strengths and weaknesses. The FASEB Journal, 22(2), 338-342.

Felsenstein, D. (1994). University-related science parks - "seedbeds" or "enclaves" of innovation? Technovation, 14(2), 93-110.

Foxall, G. R. (1995). Cognitive styles of consumer initiators. Technovation, 15(5), 269-288.

Füller, J., \& Matzler, K. (2007). Virtual product experience and customer participation-A chance for customercentred, really new products. Technovation, 27(6-7), 378-387.

Furrer, O., Kerguignas, J. Y., Delcourt, C., \& Gremler, D. D. (2020). Twenty-seven years of service research: a literature review and research agenda. Journal of Services Marketing, available online ahead of print at https://doi.org/10.1108/JSM-02-2019-0078.

Garfield, E. (1990). How ISI Selects Journals for Coverage: Quantitative and Qualitative Considerations. Current Contents, May 28, 5-13. Reprinted in Essays of an Information Scientist, 13(22), 185-193.

Gifi, A. (1990). Nonlinear multivariate analysis, Wiley, Chichester.

González-Loureiro, M., Dabić, M., \& Furrer, O. (2015). A content and comparative analysis of strategic management research in the Baltic area. Baltic Journal of Management, 10(2), 243-266. 
Grimaldi, R., \& Grandi, A. (2005). Business incubators and new venture creation: An assessment of incubating models. Technovation, 25(2), 111-121.

Guan, J., \& Ma, N. (2003). Innovative capability and export performance of Chinese firms. Technovation, 23(9), 737-747.

Guderian, C. C., Bican, P. M., Riar, F. J., \& Chattopadhyay, S. (2021). Innovation management in crisis: patent analytics as a response to the COVID- 19 pandemic. $R \& D$ Management, 51(2), 223-239.

Hadjimanolis, A. (1999). Barriers to innovation for SMEs in a small less developed country (Cyprus). Technovation, 19(9), 561-570.

Hair, J. H. Jr, Anderson, R. E., Tatham, R. L., \& Black, W. C. (1998). Multivariate Data Analysis, 5th edition. Upper Saddle River, NJ: Prentice Hall.

Hannigan, T., Haans, R. F. J., Vakili, K., Tchalian, H., Glaser, V., Wang, M., Kaplan, S., \& Jennings, P. D. (2019). Topic modeling in management research: Rendering new theory from textual data. Academy of Management Annals, 13(2), 586-632.

Havemann, F., \& Larsen, B. (2015). Bibliometric indicators of young authors in astrophysics: Can later stars be predicted?. Scientometrics, 102(2), 1413-1434.

Hayward, G. (1996) Editorial, Technovation, 16(1), 3-3

Hoffman, D. L., \& De Leeuw, J. (1992). Interpreting multiple correspondence analysis as a multidimensional scaling method. Marketing Letters, 3(3), 259-272.

Hoffman, K., Parejo, M., Bessant, J., \& Perren, L. (1998). Small firms, R\&D, technology and innovation in the UK: A literature review. Technovation, 18(1), 39-55.

Hu, K., Wu, H., Qi, K., Yu, J., Yang, S., Yu, T., Zheng, J. \& Liu, B. (2018). A domain keyword analysis approach extending Term Frequency-Keyword Active Index with Google Word2Vec model. Scientometrics, 114(3), 1031-1068.

Huizingh, E. K. R. E. (2011). Open innovation: State of the art and future perspectives. Technovation, 31(1), 29.

Irani, Z., Ezingeard, J. N., \& Grieve, R. J. (1997). Integrating the costs of a manufacturing it/is infrastructure into the investment decision-making process. Technovation, 17(11-12), 695-706.

Jiao, J., Ma, Q., \& Tseng, M. M. (2003). Towards high value-added products and services: Mass customization and beyond. Technovation, 23(10), 809-821.

Kano, N. (1984) Attractive quality and must be quality, Hinshitsu (Quality), 14(2), pp. 147-156 (in Japanese).

Kiessling, T., Vlacic, B., \& Dabić, M. (2019). Mapping the future of cross-border mergers \& acquisitions. IEEE Transactions on Engineering Management, available online ahead of print: 10.1109/TEM.2019.2954799

Kwak, Y. H., \& Anbari, F. T. (2006). Benefits, obstacles, and future of six sigma approach. Technovation, 26(56), 708-715.

Kwak, Y. H., \& Stoddard, J. (2004). Project risk management: Lessons learned from software development environment. Technovation, 24(11), 915-920.

Lee, J., Lee, J., \& Souder, W. E. (2000). Differences of organizational characteristics in new product development: Cross-cultural comparison of Korea and the US. Technovation, 20(9), 497-508.

Lee, L. W., Dabirian, A., McCarthy, L. P., \& Kietzmann, J. (2020). Making Sense of Text:Artificial IntelligenceEnabled Content Analysis. European Journal of Marketing, 54(3), 615-644. 
Lee, S., Yoon, B., \& Park, Y. (2009). An approach to discovering new technology opportunities: Keyword-based patent map approach. Technovation, 29(6-7), 481-497.

Lewis, S. C., Zamith, R. \& Hermida, A. (2013). Content analysis in an era of big data: a hybrid approach to computational and manual methods, Journal of Broadcasting and Electronic Media, 57(1), 34-52.

Lin, H. F., \& Lin, S. M. (2008). Determinants of e-business diffusion: A test of the technology diffusion perspective. Technovation, 28(3), 135-145.

Linstone, H. A. (1999). TFSC: 1969-1999. Technological Forecasting and Social Change, 62(1-2), 1-8.

Linton, J. (2011). What does journal fit and focus look like: A visual representation. Technovation, 12(31), 613614.

Linton, J. D., \& Embrechts, M. (2007). MOT TIM journal rankings 2006. Technovation, 3(27), 91-94.

Liu, X., \& White, R. S. (1997). The relative contributions of foreign technology and domestic inputs to innovation in Chinese manufacturing industries. Technovation, 17(3), 119-125.

Lüthje, C. (2004). Characteristics of innovating users in a consumer goods field: An empirical study of sportrelated product consumers. Technovation, 24(9), 683-695.

Marzi, G., Caputo, A., Garces, E., \& Dabić, M. (2020a). A Three Decade Mixed-Method Bibliometric Investigation of the IEEE Transactions on Engineering Management. IEEE Transactions on Engineering Management, 67(1), 4-17.

Marzi, G., Ciampi, F., Dalli, D., \& Dabić, M. (2020b). New product development during the last ten years: the ongoing debate and future avenues. IEEE Transactions on Engineering Management.

Matzler, K., \& Hinterhuber, H. H. (1998). How to make product development projects more successful by integrating Kano's model of customer satisfaction into quality function deployment. Technovation, 18(1), 2538.

Merino, M. T. G., Do Carmo, M. L. P., \& Álvarez, M. V. S. (2006). 25 Years of Technovation: characterisation and evolution of the journal. Technovation, 26(12), 1303-1316.

Mian, S. A. (1994). US university-sponsored technology incubators: an overview of management, policies and performance. Technovation, 14(8), 515-528.

Mikkola, J. H. (2001). Portfolio management of R\&D projects: Implications for innovation management. Technovation, 21(7), 423-435.

Mu, J., Peng, G., \& MacLachlan, D. L. (2009). Effect of risk management strategy on NPD performance. Technovation, 29(3), 170-180.

Narula, R. (2004). R\&D collaboration by SMEs: New opportunities and limitations in the face of globalisation. Technovation, 24(2), 153-161.

Narula, R., \& Hagedoorn, J. (1999). Innovating through strategic alliances: Moving towards international partnerships and contractual agreements. Technovation, 19(5), 283-294.

Ndonzuau, F. N., Pirnay, F., \& Surlemont, B. (2002). A stage model of academic spin-off creation. Technovation, 22(5), 281-289.

Nieto, M. J., \& Santamaría, L. (2007). The importance of diverse collaborative networks for the novelty of product innovation. Technovation, 27(6-7), 367-377.

Nieto, M., \& Quevedo, P. (2005). Absorptive capacity, technological opportunity, knowledge spillovers, and innovative effort. Technovation, 25(10), 1141-1157. 
Obradović, T., Vlačić, B., \& Dabić, M. (2021). Open innovation in the manufacturing industry: A review and research agenda. Technovation, available online ahead of print at https://doi.org/10.1016/j.technovation.2021.102221.

Pappas, I. O., \& Woodside, A. G. (2021). Fuzzy-set Qualitative Comparative Analysis (fsQCA): Guidelines for research practice in Information Systems and marketing. International Journal of Information Management, available online ahead of print at: https://doi.org/10.1016/j.ijinfomgt.2021.102310

Pauwels, C., Clarysse, B., Wright, M., \& Van Hove, J. (2016). Understanding a new generation incubation model: The accelerator. Technovation, 50-51(SI), 13-24.

Perdomo-Ortiz, J., González-Benito, J., \& Galende, J. (2006). Total quality management as a forerunner of business innovation capability. Technovation, 26(10), 1170-1185.

Persson, O., Danell, R., \& Schneider, J. W. (2009). How to use Bibexcel for various types of bibliometric analysis. Celebrating Scholarly Communication Studies: A Festschrift for Olle Persson at His 60th Birthday, 5, 9-24. Retrieved from <http://lup.lub.lu.se/record/1458990/file/1458992.pdf\#page=11> (last accessed 14.05.2020).

Pinto, J. K., \& Covin, J. G. (1989). Critical factors in project implementation: a comparison of construction and R\&D projects. Technovation, $9(1), 49-62$.

Prajogo, D. I., \& Sohal, A. S. (2001). TQM and innovation: A literature review and research framework. Technovation, 21(9), 539-558.

Prajogo, D. I., \& Sohal, A. S. (2004). The multidimensionality of TQM practices in determining quality and innovation performance - An empirical examination. Technovation, 24(6), 443-453.

Pujari, D. (2006). Eco-innovation and new product development: Understanding the influences on market performance. Technovation, 26(1), 76-85.

Quintana-García, C., \& Benavides-Velasco, C. A. (2004). Cooperation, competition, and innovative capability: A panel data of European dedicated biotechnology firms. Technovation, 24(12), 927-938.

Quintas, P., Wield, D., \& Massey, D. (1992). Academic-industry links and innovation: questioning the science park model. Technovation, 12(3), 161-175.

Ragin, C. C. (1987). The comparative method: Moving beyond qualitative and quantitative strategies. University of California Press, CA.

Rasmussen, E. A., \& Sørheim, R. (2006). Action-based entrepreneurship education. Technovation, 26(2), 185194.

Rasmussen, E., Moen, Ø., \& Gulbrandsen, M. (2006). Initiatives to promote commercialization of university knowledge. Technovation, 26(4), 518-533.

Rialp, A., Merigó, J. M., Cancino, C. A., \& Urbano, D. (2019). Twenty-five years (1992-2016) of the International Business Review: A bibliometric overview. International Business Review, available online ahead of print: https://doi.org/10.1016/j.ibusrev.2019.101587.

Ritala, P., Olander, H., Michailova, S., \& Husted, K. (2015). Knowledge sharing, knowledge leaking and relative innovation performance: An empirical study. Technovation, 35, 22-31.

Rogers, E. M. (1986). The role of the research university in the spin-off of high-technology companies. Technovation, 4(3), 169-181.

Rothwell, R. (1991). External networking and innovation in small and medium-sized manufacturing firms in Europe. Technovation, 11(2), 93-112.

Rothwell, R., \& Gardiner, P. (1985). Invention, innovation, re-innovation and the role of the user: A case study of British hovercraft development. Technovation, 3(3), 167-186. 
Rousseau, D. M., Manning, J., \& Denyer, D. (2008). Evidence in management and organizational science: Assembling the field's full weight of scientific knowledge through syntheses. The Academy of Management Annals, 2(1), 475-515.

Samiee, S., \& Chabowski, B. R. (2012). Knowledge structure in international marketing: a multi-method bibliometric analysis. Journal of the Academy of Marketing Science, 40(2), 364-386.

Samsom, K. J., \& Gurdon, M. A. (1993). University scientists as entrepreneurs: a special case of technology transfer and high-tech venturing. Technovation, 13(2), 63-71.

Shehabuddeen, N., Probert, D., \& Phaal, R. (2006). From theory to practice: Challenges in operationalising a technology selection framework. Technovation, 26(3), 324-335.

Shibata, N., Kajikawa, Y., Takeda, Y., \& Matsushima, K. (2008). Detecting emerging research fronts based on topological measures in citation networks of scientific publications. Technovation, 28(11), 758-775.

Snyder, H. (2019). Literature review as a research methodology: An overview and guidelines. Journal of Business Research, 104, 333-339.

Su, H. N., \& Lee, P. C. (2010). Mapping knowledge structure by keyword co-occurrence: a first look at journal papers in Technology Foresight. Scientometrics, 85(1), 65-79.

Szmigin, I., \& Foxall, G. (1998). Three forms of innovation resistance: The case of retail payment methods. Technovation, 18(6-7), 459-468.

Tödtling, F., Lehner, P., \& Kaufmann, A. (2009). Do different types of innovation rely on specific kinds of knowledge interactions? Technovation, 29(1), 59-71.

Tranfield, D., Denyer, D., \& Smart, P. (2003). Towards a methodology for developing evidence- informed management knowledge by means of systematic review. British journal of management, 14(3), 207-222.

Tyebjee, T. T., \& Bruno, A. V. (1984). Venture capital: Investor and investee perspectives. Technovation, 2(3), 185-208.

van de Vrande, V., de Jong, J. P. J., Vanhaverbeke, W., \& de Rochemont, M. (2009). Open innovation in SMEs: Trends, motives and management challenges. Technovation, 29(6-7), 423-437.

van Eck, N. J., \& Waltman, L. (2010). Software survey: VOSviewer, a computer program for bibliometric mapping. Scientometrics, 84(2), 523-538.

van Eck, N. J., \& Waltman, L. (2014). Visualizing Bibliometric Networks. In: Y. Ding, R. Rousseau, \& D. Wolfram (Eds.) Measuring Scholarly Impact: Methods and practice (285-320). Springer.

Vedovello, C. (1997). Science parks and university-industry interaction: Geographical proximity between the agents as a driving force. Technovation, 17(9), 491-502.

Visintin, F., \& Pittino, D. (2014). Founding team composition and early performance of university-based spin-off companies. Technovation, 34(1), 31-43.

Vlačić, B., Corbo, L., Costa e Silva, S., \& Dabić, M. (2021). The evolving role of artificial intelligence in marketing: A review and research agenda. Journal of Business Research, 128, 187-203.

Watanabe, C., Tsuji, Y. S., \& Griffy-Brown, C. (2001). Patent statistics: Deciphering a "real" versus a "pseudo" proxy of innovation. Technovation, 21(12), 783-790.

Watanabe, C., Wakabayashi, K., \& Miyazawa, T. (2000). Industrial dynamism and the creation of a 'virtuous cycle' between R\&D, market growth and price reduction. The case of photovoltaic power generation (PV) development in Japan. Technovation, 20(6), 299-312.

Wognum, P. M., Fisscher, O. A. M., \& Weenink, S. A. J. (2002). Balanced relationships: Management of clientsupplier relationships in product development. Technovation, 22(6), 341-351. 
Woolthuis, R.K., Lankhuizen, M., \& Gilsing, V. (2005). A system failure framework for innovation policy design. Technovation, 25(6), 609-619.

Wu, N. C., Nystrom, M. A., Lin, T. R., \& Yu, H. C. (2006). Challenges to global RFID adoption. Technovation, 26(12), 1317-1323.

Yousafzai, S. Y., Pallister, J. G., \& Foxall, G. R. (2003). A proposed model of e-trust for electronic banking. Technovation, 23(11), 847-860.

Zeng, S. X., Xie, X. M., \& Tam, C. M. (2010). Relationship between cooperation networks and innovation performance of SMEs. Technovation, 30(3), 181-194.

Zupic, I., \& Čater, T. (2015). Bibliometric Methods in Management and Organization. Organizational Research Methods, 18(3), 429-472. 
